\title{
Mirrored Images: The Passion and the First Crusade in a Fourteenth-Century Parisian Illuminated Manuscript (Paris, Bibliotheque Nationale de France, MS fr. 352)
}

Susanna A. Throop

Ursinus College, sthroop@ursinus.edu

Follow this and additional works at: https://digitalcommons.ursinus.edu/history_fac

Part of the European History Commons, History of Christianity Commons, History of Religion Commons, $\underline{\text { Medieval History Commons, and the Medieval Studies Commons }}$

Click here to let us know how access to this document benefits you.

\section{Recommended Citation}

Throop, Susanna A., "Mirrored Images: The Passion and the First Crusade in a Fourteenth-Century Parisian Illuminated Manuscript (Paris, Bibliotheque Nationale de France, MS fr. 352)" (2015). History Faculty Publications. 7.

https://digitalcommons.ursinus.edu/history_fac/7 


\section{Mirrored Images: The Passion and the First Crusade in a Fourteenth- Century Parisian Illuminated Manuscript (BnF MS fr. 352)}

Susanna A. Throop

History Department, Ursinus College, Collegeville, USA

Dr. Susanna A. Throop, History Department, Ursinus College, 601 E. Main Street, Collegeville, PA 19426-1000, USA. Email: sthroop@ursinus.edu.

Susanna A. Throop received her Ph.D. from the University of Cambridge in 2006 and is currently Assistant Professor of History at Ursinus College. She is the author of Crusading as an Act of Vengeance, 1095-1216 (Ashgate, 2011). She has also co-edited Vengeance in the Middle Ages: Emotion, Religion, and Feud (Ashgate, 2010) and The Crusades and Visual Culture (Ashgate, under contract). The Charles Homer Haskins Society awarded her the 2012 Denis Bethell Essay Prize for her most recent article, 'Christian Community and the Crusades: Religious and Social Practices in the De expugnatione Lyxbonensi,' Haskins Society Journal 24. 


\title{
Mirrored Images: The Passion and the First Crusade in a Fourteenth- Century Parisian Illuminated Manuscript (BnF MS fr. 352)
}

\author{
Abstract: This lavish mid-fourteenth-century Parisian illuminated manuscript (BnF fr. 352) \\ combines a description of the Holy Land with an abridged version of the history and \\ continuations of William of Tyre in Old French known as the Eracles. It is both visually \\ familiar to scholars and under-studied. Several of its Gothic panel miniatures, especially \\ folio 62r, the Conquest of Jerusalem, have been published more than once, yet the \\ manuscript's illumination program as a whole has not been assessed since Jaroslav Folda's \\ 1968 doctoral dissertation. Analysis of folio $62 \mathrm{r}$ in the context of both the full illumination \\ program and the manuscript's historical context reveals that fr. 352 speaks to the desire of \\ mid-fourteenth-century French nobility to see the chivalric present mirrored by the \\ crusading past, the new western 'holy land' of Paris mirrored by the true locus sanctus of \\ Jerusalem, and the Passion mirrored by the First Crusade.
}

Keywords: Passion of Christ, Philip VI of France, Godfrey of Bouillon, Eracles, SainteChapelle, Jerusalem, First Crusade, Chivalry

\section{Introduction}

'La tres noble et excellente Ystoire des saintes croniques d'outremer et des nobles chevaleries faites et commenchies par le preu, le vaillant et le saint homme Godefroi de Buillon' ${ }^{1}$ is in the

This work was supported by the American Historical Association under a Bernadotte E. Schmitt Grant (2012) and Ursinus College under a Faculty Development Grant (2012). Dominique de Saint Etienne at Myrin Library, Ursinus College, worked patiently to order materials for me via interlibrary loan. M. Cecilia Gaposchkin, Norman Housley, Elizabeth Lapina, Richard Leson, and Laura Whatley kindly read drafts of this article and I am especially grateful for their perceptive feedback, which has strengthened the article in numerous ways. I am equally grateful for the insight provided by this journal's anonymous reviewers. All errors are, of course, my own.

${ }^{1}$ Paris, Bibliothèque nationale de France, MS fr. 352. The manuscript is listed as number 56 by Jaroslav Folda, 'Manuscripts of the History of Outremer by William of Tyre: A Handlist,' Scriptorium 27, 
unusual position of being visually familiar yet under-studied. Many crusade scholars will recognize on sight at least one relatively well-published illumination from this Parisian manuscript, ${ }^{2}$ but its illuminations as a whole have escaped a more critical gaze. This is somewhat surprising, since the date of origin for fr. 352 - circa $1350^{3}$ — places it at the end of a well-known period of intense crusade-related manuscript production in Paris, which was stimulated by the crusade plans of Philip VI Valois of France (r. 1328-50) in the 1330s. It is even more surprising since it is one of 78 manuscripts that contain some version or portion of the history of William of Tyre. ${ }^{4}$

Fr. 352 is a single, three-column manuscript with 35 lines of text in each column. It contains 175 folios $^{5}$ followed by an unusual colophon, discussed at greater length below. The

no. 1 (1973): 90-95. The most recent and complete work on the manuscript (including a catalog) remains Jaroslav Folda, 'The Illustrations in Manuscripts of the History of Outremer by William of Tyre,' 2 vols. (PhD diss., The Johns Hopkins University, 1968). See esp. 1:402-40 and 2:251-60. Paulin Paris briefly discussed the manuscript in Les Manuscrits François de La Bibliothèque du Roi (Paris: Techener, 1840), 3:5-9.

${ }^{2}$ Fol. 62r. Published in Norman Housley, Fighting for the Cross: Crusading to the Holy Land (New Haven: Yale University Press, 2008), plate 11 and Susanna Throop, Crusading as an Act of Vengeance, 1095-1216 (Aldershot: Ashgate Publishing, 2011), cover image. Fol. 49v is also relatively recognizable; for example, it was published in Michel Parisse, 'Godefroy de Bouillon, le croisé exemplaire,' L'histoire 47 (1982): 21.

${ }^{3}$ Folda, 'The Illustrations in Manuscripts,' 1:449. I discuss the dating further below at pp. 00-00.

${ }^{4}$ Folda, 'Handlist.'

${ }^{5}$ For more on manuscript production in Paris in the fourteenth century, see Mary and Richard Rouse, Manuscripts and their Makers: Commercial Book Producers in Medieval Paris, 1200-1500, 2 vols. (Washington, D.C.: Harvey Miller Publishers, 2000). For more on reading Old French narrative manuscripts, see Keith Busby, Codex and Context: Reading Old French Verse Narrative in Context, 2 vols. (Amsterdam: Editions Rodopi B. V., 2002). Earlier relevant studies on illuminated manuscripts include Jonathan J. G. Alexander, 'Art History, Literary History, and the Study of 
first ten folios describe the holy places in the Levant while the rest contain an abridged version of the history and continuations of William of Tyre in Old French, known as the Eracles. ${ }^{6}$ Because it is an abridged version of the Eracles, fr. 352 has been largely excluded from textual analysis of the Old French William of Tyre. ${ }^{7}$ Similarly, in part because it is a product of ateliers Medieval Illuminated Manuscripts,' Studies in Iconography 18 (1997): 51-66; Jeffrey Hamburger, 'The Visual and the Visionary: The Image in Late Medieval Monastic Devotions,' Viator 20 (1989): 161-82; Michael Camille, 'Seeing and Reading: Some Visual Implications of Medieval Literacy and Illiteracy,' Art History 8 (1985): 26-49; Lesley Lawton, 'The Illustration of Late Medieval Secular Texts, with Special Reference to Lydgate's 'Troy Book,' in Manuscripts and Readers in FifteenthCentury England, ed. Derek Pearsall (Cambridge: D. S. Brewer, 1983): 41-69.

${ }^{6}$ The manuscript's continuation ends with the conclusion of the Seventh Crusade in 1254 (Folda, 'The Illustrations in Manuscripts,' 2:251), and thus is counted with those manuscripts with continuations that end before 1261 (Folda, 'Handlist,' 94-5). The fact that the William of Tyre continuation in fr. 352 begins on fol. 11r by referencing Eracles in text and rubric (Folda, 'The Illustrations in Manuscripts,' 2:253) places it in the Eracles tradition. Peter Edbury is currently preparing a new edition of the Eracles; excerpts from this work can be found at http://www.fordham.edu/halsall/basis/GuillaumeTyr4.asp. In the meantime, the Old French translation of William of Tyre's chronicle can be found in Guillaume de Tyr et ses continuateurs, ed. M. Paulin Paris (Paris: Firmin-Didot, 1879).

${ }^{7}$ For example, the manuscript is not addressed in Peter Edbury, 'New Perspectives on the Old French Continuations of William of Tyre,' Crusades 10 (2010): 107-13; Peter Edbury, 'The French Translation of William of Tyre's Historia: the Manuscript Tradition,' Crusades 7 (2007): 69-105; Bernard Hamilton, 'The Old French translations of William of Tyre as an historical source,' in The Experience of Crusading 2: Defining the Crusader Kingdom, ed. Peter Edbury and Jonathan Phillips (Cambridge: Cambridge University Press, 2003), 93-112; John H. Pryor, 'The Eracles and William of Tyre: An Interim Report,' in The Horns of Hattin, ed. Benjamin Z. Kedar (Jerusalem: Yad Izhak Ben-Zvi,1992), 270-93; Peter Edbury, 'The Lyon Eracles and the Old French Continuations of William of Tyre,' in Montjoie: Studies in Crusade History in Honour of Hans Eberhard Mayer, ed. Benjamin Z. Kedar, Jonathan S.C. Riley-Smith, and R. Hierstand (Aldershot: Ashgate, 1997), 13953; Margaret R. Morgan, The Chronicle of Ernoul and the Continuations of William of Tyre (Oxford: Oxford University Press, 1973). Professor Edbury has kindly informed me that because of 
in Paris rather than the Levant, the most recent analysis of its illuminations remains Jaroslav Folda's 1968 doctoral dissertation. ${ }^{8}$

This relative lack of attention is not due to a lack of interesting visual features. Fr. 352 contains a planned program of 39 fully coloured and often gilded Gothic miniatures (Table 1). While its increased number and uneven distribution of miniatures, similar style and iconography, and a mid-fourteenth-century date link fr. 352 with other manuscripts in what Folda has called the 'Expanded Cycle' group of manuscripts, ${ }^{9}$ its illumination program departs from the group in several ways. Uniquely in the group, fr. 352 begins with a panel miniature depicting the city of Jerusalem, in and around which moments of Christ's life, most notably the Passion, are

the abbreviated nature of fr. 352's version of the Eracles, it will not be included in the new critical edition he is producing.

${ }^{8}$ See n. 1 above. Since 1968, Folda has done substantial work on illuminated manuscripts of William of Tyre produced in the Levant: Crusader Manuscript Illumination at Saint-Jean d'Acre, 1275-91 (Princeton: Princeton University Press, 1976). More recently on these Levantine manuscripts, see Bianca Kühnel, 'The Perception of History in Thirteenth-Century Crusader Art' in France and the Holy Land: Frankish Culture at the End of the Crusades, ed. Daniel H. Weiss and Lisa Mahoney (Baltimore: The Johns Hopkins University Press, 2004), 161-86. Recent work on other Parisian William of Tyre manuscripts (excluding fr. 352) includes Folda, 'Commemorating the Fall of Jerusalem: Remembering the First Crusade in Text, Liturgy, and Image,' in Remembering the Crusades: Myth, Image, and Identity, ed. Nicholas Paul and Suzanne Yeager (Baltimore: The Johns Hopkins University Press, 2012), 125-45 and Richard A. Leson, 'Chivalry and Alterity: Saladin and the Remembrance of Crusade in a Walters Histoire d'Outremer,' The Journal of the Walters Art Museum 68-69 (2010-11): 87-96.

${ }^{9}$ Paris, Bibliothèque nationale de France, MS fr. 22495; Paris, Bibliothèque nationale de France, MS fr. 352; Baltimore, Walters Art Museum, MS W.142; Paris, Bibliothèque nationale de France, MS fr. 9083; Paris, Bibliothèque nationale de France, MS fr. 22496-7; Paris, Bibliothèque nationale de France, MS fr. 24209. For more details on the common characteristics of the group, see Folda, 'The Illustrations in Manuscripts,' 1:403. 
depicted. ${ }^{10}$ Another significant departure is the frenetic cluster of miniatures surrounding the siege and capture of Antioch in 1098 during the First Crusade. ${ }^{11}$ Finally, the relatively wellknown panel miniature from folio 62r, which dramatically depicts First Crusaders attacking the city of Jerusalem in 1099 , is also unique. ${ }^{12}$

My primary concern here is a deceptively simple question about the panel miniature on folio 62r: what does this illumination, particularly its juxtaposition of the Passion and the First Crusade, tell us about ideas of crusading in fourteenth-century France? Answering this question requires consideration of the miniature's context in addition to its iconography. At the most fundamental level, this context includes the other illuminations in the manuscript. The miniature on folio $62 \mathrm{r}$ is not an isolated image, and only by considering it in light of the manuscript's illumination program as a whole are we likely to approach an accurate understanding of the meaning/s it conveyed to fourteenth-century contemporaries. In addition, the historical context of the image—its audience and the events and trends surrounding its creation—deserves attention.

In what follows I will first briefly outline the miniatures of the manuscript, building upon the foundation laid by Folda. Next, I will discuss the manuscript's intended audience or patron, arguing against royal patronage and for a connection to the mid-fourteenth-century French nobility instead. Finally, I will analyse folio 62r's panel miniature in greater detail, on its own

${ }^{10}$ Fol. 1r. While other manuscripts in the 'Expanded Cycle' group do include miniatures related to Christ's life and death in the Holy Land in early folios, they situate those images firmly in a crusading context; three by leading with miniatures depicting Peter the Hermit (W. 142, fr. 22496-7, fr. 24209), one by leading with a miniature of King Amalric alongside miniatures of Old and New Testament scenes (fr. 22495), and one by showing the First Crusaders besieging Jerusalem (fr. 9083). For details, see Folda, 'The Illustrations in Manuscripts,' 2:140, 177, 202, 219.

${ }^{11}$ Fols. 47v, 48r, 48v, 49. Folda highlights this departure from the group program in 'The Illustrations in Manuscripts,' 1:422.

${ }^{12}$ Folda notes this departure in 'The Illustrations in Manuscripts,' 1:424. 
and in the context of the full program of illuminations. Ultimately I will argue that the illumination program, in particular the prominence of folios $1 \mathrm{r}$ and $62 \mathrm{r}$, speaks to the desire of the fourteenth-century French nobility to see the chivalric present mirrored by the crusading past, the new western 'holy land' of Paris mirrored by the true locus sanctus of Jerusalem, and the Passion mirrored by the First Crusade. Fr. 352 was designed to allow the viewer to see him/herself and present circumstances in the past, thus encouraging continued devotion to the crusade ideal.

\section{Summary of the manuscript's miniatures}

As noted, fr. 352 is a single, three-column manuscript with 39 fully coloured and often gilded Gothic miniatures, including illuminated book and chapter initials, some rubrics, and notes for the rubricator. The colours most heavily used are blue and blue-grey, red/russet, yellow/gold, and taupe, with some green for foliage. Gilding is used to highlight architectural structures, haloes, crosses, and also in some initials and coats of arms. While most miniatures are column miniatures, there are three larger panel miniatures. ${ }^{13}$

Indeed, the manuscript begins with a dramatic half-page miniature depicting the city of Jerusalem, the Passion and Ascension of Christ, and the Dormition of the Virgin. ${ }^{14}$ In the right margin we see a long-necked bird surmounted by a monkey, ${ }^{15}$ while the bas-de-page illumination

\footnotetext{
${ }^{13}$ Fols. 1r, 49v, 62r.

${ }^{14}$ Fol. 1r. The use of major introductory panel miniatures is a characteristic shared among the 'Expanded Cycle' group of manuscripts, though none of the others take precisely the same approach as fr. 352; see note 10 above.

${ }^{15}$ The bird has one foot raised and appears to be poking or spearing the rear end of the monkey, whose legs are spread and who is holding a spherical object (a fruit or nut?) to its mouth. It is commonly known that a monkey or ape frequently signifies represents the devil; this dates back at least to the earliest Physiologus (ed. and trans. Michael J. Curley, 2nd ed. (Chicago: University of Chicago
} 
shows two hounds chasing a stag from right to left. Four coats of arms are depicted along the bottom and right margin: France, England, Navarre, and Lorraine.

In the subsequent portion of the manuscript describing the holy places, all nine miniatures, including the one just described, relate to the life of Christ. ${ }^{16}$ While it is not surprising that the life of Christ features heavily, it is nonetheless notable that none of the miniatures address any saints or moments in the history of Jerusalem. Furthermore, the miniatures do not focus on the entire life of Christ equally; with one exception the miniatures focus on the beginning and end of Christ's human life, the Nativity and the Passion. ${ }^{17}$ His preaching and miracles are not depicted, with the exception of the raising of Lazarus ${ }^{18}$-an episode that foreshadows Christ's resurrection and his ability to save the souls of the faithful.

Press, 2009), 38-9). The presence of the fruit or nut is reminiscent of one of Gilbert of Tournai's thirteenth-century crusade sermons, in which he exhorts his audience to be unlike the monkey, which 'throws away the nut while it senses the outer bitterness in its skin, never perceiving the sweetness of its centre' (Gilbert of Tournai, 'Sermo 1,' in Crusade Propaganda and Ideology. Model Sermons for the Preaching of the Cross, ed. Christoph T. Maier (Cambridge: Cambridge University Press, 2000), 188. The kind of bird represented is unclear to my inexpert eyes; it is, perhaps, a heron or crane, and seems unlikely to be a pelican or phoenix (either of which would signify Christ). On the heron, the Physiologus cites Psalms 104:17-'the heron is leader of their house' - and notes the bird's prudence in having only one nest in which it eats, suggesting that this is like remaining in the 'nest' of the Church and eating only its food, i.e., avoiding heresy (40). Thus, perhaps this marginale represents the pursuit and injury of the devil by the head of a godly family or lineage, and draws a parallel between this pursuit of the devil and crusading. For more on bestiary images in the margins of later medieval manuscripts, see Debra Hassig, 'Marginal Bestiaries,' in Animals and the Symbolic in Mediaeval Art and Literature, ed. L. A. J. R. Houwen (Groningen: Egbert Forsten, 1997), 171-88.

\footnotetext{
${ }^{16}$ Fols. 1r-10v.

${ }^{17}$ Fols. 2r, 2v, 4v, 5v, 6v, 10v.

${ }^{18}$ Fol 1v.
} 
In the remainder and majority of the manuscript, quantitatively the miniatures most heavily emphasize two main themes: events at Antioch during the First Crusade, and noble and royal individuals and families. ${ }^{19}$ A staggering seventeen miniatures outline events at Antioch in 1098 , including the betrayal of the city by one of its own, ${ }^{20}$ the finding of the Holy Lance, ${ }^{21}$ and a dramatic half-page miniature of crusaders and Turks engaged in pitched battle among the Turks' tents outside the walls of Antioch. ${ }^{22}$ The Antioch sequence is followed by a miniature depicting God showing Godfrey of Bouillon and other crusaders a vision of a knight during the siege of Jerusalem ${ }^{23}$ and then the panel miniature on folio $62 \mathrm{r}$. This is followed by a miniature showing the discovery of the True Cross. ${ }^{24}$ Of the remaining eight miniatures, six illustrate the coronations of various kings of Jerusalem from Baldwin I (r. 1100-1118) through Guy of Lusignan (r. 1186-1192). ${ }^{25}$

The relative visual absence of Muslims sets fr. 352 clearly apart from other manuscripts in the 'Expanded Cycle' group, most notably Walters $142 .{ }^{26}$ Muslims are only depicted in four column miniatures, and when they are present, they are in the minority, dominated by a visual majority of crusaders. ${ }^{27}$ There are no Muslims in the city of Jerusalem when the First Crusaders storm the walls, nor are there any in the depiction of the siege of Tyre. ${ }^{28}$ And while one panel

\footnotetext{
${ }^{19}$ Fols. 11r-174v.

${ }^{20}$ Fol. 42v.

${ }^{21}$ Fol 46v.

${ }^{22}$ Fol 49v.

${ }^{23}$ Fol. 61r.

${ }^{24}$ Fol. 64v.

${ }^{25}$ Fols. 72r, 87r, 107v, 135v, 140r, 154v.

${ }^{26}$ Leson, 'Chivalry and Alterity,' 87-96.

${ }^{27}$ Fols. 28r, 42v, 49v, 61r.

${ }^{28}$ Fols. 62r, 93r.
} 
miniature depicts crusaders and Turks in battle outside Antioch, it is preceded by twelve column miniatures showing the various crusading contingents marching out of the city without an enemy in sight. Similarly, Jews are only depicted in four miniatures, and while they are visually distinguishable (by beards and stereotypical pointed hats) and depicted playing negative roles in Christ's passion, they are not overtly demonized. ${ }^{29}$

\section{The manuscript's intended audience}

A reading of a manuscript's miniatures depends upon the presumed identity of the viewer. Thus we must ask: for whom was this luxurious manuscript, so rich in material and meaning, intended? As noted, fr. 352 was produced in Paris in the mid-fourteenth century. Given the prominent coats of arms,${ }^{30}$ repeated hunting motifs, ${ }^{31}$ depictions of warfare including three major sieges, ${ }^{32}$ careful illustration of eleven military leaders and their contingents at Antioch, ${ }^{33}$ and miniatures showing the crowning of no less than six kings of Jerusalem, ${ }^{34}$ as well as the use of the vernacular and the obvious quality (and thus cost) of the manuscript, it seems reasonable to conclude it was intended for a member of the French upper nobility or royal court. ${ }^{35}$ Can we say more than this?

${ }^{29}$ Fols. 1r, 4v, 5v, 62r. The definitive work on demonizing images of Jews and Muslims is Debra Higgs Strickland, Saracens, Demons, and Jews: Making Monsters in Medieval Art (Princeton: Princeton University Press, 2003).

${ }^{30}$ Fol. 1r.

${ }^{31}$ Fols. 1r, 62r.

${ }^{32}$ Antioch, Jerusalem, and Tyre; see fols. 42v, 61r, 62r, 93r.

${ }^{33}$ Hugh the Great, Robert of Flanders, Robert of Normandy, Adhémar of Le Puy, Raymond of Toulouse, Raimbaud of Orange, Godfrey of Bouillon, Tancred of Sicily, Hugh of St. Pol, Rotrou of Perch, Ysoard of Die.

${ }^{34}$ Baldwin I, Baldwin II, Baldwin III, Amalric I, Baldwin IV, Guy of Lusignan.

${ }^{35}$ Folda, 'The Illustrations in Manuscripts,' 1:452-3. 
Folda placed the entire 'Expanded Cycle' group of manuscripts (which includes fr. 352) within the 'thirty years surrounding 1350. ${ }^{36}$ More specifically, he assigned fr. 352 an approximate date of origin of 1350 based on the iconographical stemma he constructed for the 'Expanded Cycle' group. ${ }^{37}$ This stemma posited BnF MS fr. 22495 as the earliest in this group; fr. 22495 is, unusually, dated in its colophon to $1337-38 .^{38}$ Folda concluded that fr. 22495 dates before rather than after the other five manuscripts in the group, and linked fr. 352 to BnF MSS. fr. 22496 and fr. 22497 via workshop tradition, noting that fr. 352 is unusual within the group for the reasons noted above $\mathrm{e}^{39}$ as well as for its lack of numbering system and lack of instructions for the artist. ${ }^{40}$ A date circa 1350 would situate fr. 352 within either the later reign of Philip VI of France or the reign of his son, John II (r. 1350-64).

There is circumstantial reason to imagine a date of origin for fr. 352 in the 1330s, i.e., contemporary rather than subsequent to fr. 22495. In the late 1320s and 1330s the court of Philip VI buzzed with plans for a new crusade. ${ }^{41}$ Early notions of assisting the Spanish kings gave way in the 1330s to the idea of a grand passagium generale to reclaim the Holy Land. ${ }^{42}$ A great number of crusading manuscripts were created in this milieu; some were illuminated manuscripts

\footnotetext{
${ }^{36}$ Ibid., 1:449.

${ }^{37}$ Ibid., 1:477.

${ }^{38}$ Ibid., 1:404.

${ }^{39}$ See p. 3 and n. 10 above.

${ }^{40}$ Folda, 'The Illustrations in Manuscripts,' 1:428, 442, 446.

${ }^{41}$ Norman Housley, The Later Crusades: From Lyons to Alcazar, 1274-1580 (Oxford: Oxford University Press, 1992), 33-6; Christopher J. Tyerman, 'Philip VI and the Recovery of the Holy Land,' The English Historical Review 100, no. 394 (1985): 25-52.

${ }^{42}$ Tyerman, 'Philip VI,' 26-7.
} 
celebrating a long crusading tradition, ${ }^{43}$ while others contained proposals or plans for the new crusade itself. ${ }^{44}$ We also know that Philip envisaged a multinational expedition; the king of Navarre was involved in the plans, as was Edward III of England. ${ }^{45}$ As noted, fr. 352 positions the arms of France, England, and Navarre in prominent positions on folio 1r.

Given Philip VI's enthusiasm for crusading, is it possible that fr. 352, like so many other Parisian manuscripts at the time, was created for royal consumption? The points already noted, as well as the sumptuousness of the manuscript and the illumination program's emphasis on royal coronations in the Kingdom of Jerusalem, seem to support the idea of a royal audience. In addition, fr. 352 was at one time housed in the Bibliotheca Regia in Paris, ${ }^{46}$ and the manuscript's highly unusual colophon references the king, albeit obliquely. The colophon appears to state that the lord who 'wrote' the book was wrongly imprisoned for seven years as a result of false accusations, and as a result his heirs have been disinherited. The king should, therefore, do his duty to them, and it will be a sin if he does not. ${ }^{47}$

${ }^{43}$ Maureen Quigley, 'Romantic Geography and the Crusades: British Library Royal ms. 19 D 1,' Peregrinations 2, no. 3 (2009): 56-7. She includes fr. 22495 in this group.

${ }^{44}$ Tyerman, 'Philip VI,' 35; Marianne Sághy, 'Crusade and Nationalism: Pierre Dubois, the Holy Land, and French Hegemony,' in The Crusades and the Military Orders: Expanding the Frontiers of Medieval Latin Christianity, ed. Zsolt Hunyadi and József Laszlovsky (Budapest: CEU Medievalia, 2001), 43-50.

${ }^{45}$ Tyerman, 'Philip VI,' 29-32. It used to be believed that the English commitment to crusade in the early fourteenth century was hesitant or superficial at best, but the opposite has been decisively demonstrated by Timothy Guard in Chivalry, Kingship and Crusade: The English Experience in the Fourteenth Century (Woodbridge: Boydell \& Brewer, 2013).

${ }^{46}$ Folda, 'The Illustrations in Manuscripts,' 2:251.

${ }^{47}$ There are two transcripts of the colophon: Folda, 'Illustrations in the Manuscripts,' 2:260 and Paris, Les Manuscrits, 3:8. My thanks to Frances Novack (Ursinus College), Elizaveta Strakhov (University of 
This rebuke seems unlikely to appeal to a royal ego. Even if we are willing to consider that such an admonishing colophon might have been presented to a king, it is difficult to understand the total absence of French monarchs from the manuscript's illuminations, given a royal audience. Unlike every other manuscript in the 'Expanded Cycle' group, ${ }^{48}$ fr. 352's illuminations do not show the role played by French monarchs in any crusading events; instead, they focus on Godfrey of Bouillon above all, as well as other members of the nobility. There is not one illumination depicting French royal involvement in the First, Second, or Third Crusade, or the crusades of Louis IX (a Valois ancestor). ${ }^{49}$ Philip VI's crusade plans in the 1330s placed him squarely at the forefront of the enterprise, in the role of 'Rector and Captain-general'; 50 would such a king (or his successor, John II) welcome a manuscript that completely omitted the French monarchy from its program of illuminations? It is equally difficult to see why either Philip or John would want the arms of Lorraine displayed alongside royal arms on folio 1r, or, indeed, why either would appreciate the arms of France, England, Navarre, and Lorraine

Pennsylvania), and Nicholas Paul (Fordham University) for their generous counsel and translation assistance on the colophon. Sadly, I have been unable to identify the 'lord' in the colophon.

${ }^{48}$ Paris, Bibliothèque nationale de France, MS fr. 24209, fols. 170r, 272r, 325r (Folda, 'The Illustrations in Manuscripts,' 2:269, 273-4); Baltimore, Walters Art Museum, MS W. 142, fols. 315v, 320v, 326r (Folda, 'The Illustrations in Manuscripts,' 2:152); Paris, Bibliothèque nationale de France, MS fr. 9083, fols. 269r, 320v (Folda, 'The Illustrations in Manuscripts,' 2:216-17); Paris, Bibliothèque nationale de France, MS fr. 22495, fols. 153r, 241v, 287r, 294v (Folda, 'The Illustrations in Manuscripts,' 2:189, 196, 200); Paris, Bibliothèque nationale de France, MS fr. 22496 fol. 104r and fr. 22497 fols. 17v, 174v, 190r (Folda, 'The Illustrations in Manuscripts,' 2:226, 232, 248-9).

${ }^{49}$ That crusading was seen as an important component of Louis's (and by extension, French royal) piety and kingship in the early fourteenth century has been demonstrated by M. Cecilia Gaposchkin, The Making of Saint Louis: Kingship, Sanctity, and Crusade in the Later Middle Ages (Ithaca, NY: Cornell University Press, 2010), 197-239, esp. 236-8.

${ }^{50}$ Housley, The Later Crusades, 34. 
displayed as apparent co-equals, with parallel scale and placement. ${ }^{51}$ Similarly, although the coronations of twelfth-century kings of Jerusalem are depicted, it is worth remembering that those kings were originally of French noble birth; Baldwin I was the brother of Godfrey of Bouillon, the clear hero of fr. 352.

It is thus tempting to see fr. 352 as homage to the late eleventh and early twelfth centuries, an era in which noble families played as great a crusading role, if not greater, than the royal house. The manuscript could also be seen in light of the thirteenth-century tradition of vernacular historiography among noble families first described by Gabrielle Spiegel. ${ }^{52}$ Folda has argued otherwise concerning the 'Expanded Cycle' group, that in the early fourteenth century William of Tyre manuscripts were no longer records of 'living history in which the patron or a close relative took part. ${ }^{53}$ That said, Elizabeth Moodey has shown that illuminated manuscripts continued to play precisely such a role up into the fifteenth century. ${ }^{54}$ It seems possible that the trend may have continued closer to Paris as well. Furthermore, we know that one of the reasons why Philip VI's calls for crusade met with relative (though not unbounded) enthusiasm within

${ }^{51}$ It should be noted that when John agreed to crusade in 1363, he agreed to co-lead with Peter I of Lusignan, King of Cyprus, rather than monarchs of England and/or Navarre (Housley, The Later Crusades, 40).

${ }^{52}$ Gabrielle M. Spiegel, Romancing the Past: The Rise of Vernacular Prose Historiography in ThirteenthCentury France (Berkeley, Los Angeles, and London: University of California Press, 1993).

${ }^{53}$ Folda, 'The Illustrations in Manuscripts,' 1:452.

${ }^{54}$ Elizabeth J. Moodey, 'Historical Identity in the Burgundian Netherlands: The Role of Manuscripts,' in Tributes in Honor of James H. Marrow: Studies in Painting and Manuscript Illumination of the Late Middle Ages and Northern Renaissance, ed. Jeffrey F. Hamburger and A. S. Korteweg (London and Turnhout: Harvey Miller, 2006), 343-51. 
France was the continued emphasis on crusading in multiple generations of various noble families. ${ }^{55}$

Given the presence of Lorraine's coat of arms on folio 1, it is natural to wonder if the manuscript was intended for the dukes of Lorraine. In order to assess this, a brief review of relevant history is necessary. The arms of France and Navarre on folio 1 remind us of the 1284 marriage of Philip IV of France (r. 1285-1314) to Joan I of Navarre. Previously, in 1255 Theobald II of Lorraine (r. 1303-12) had married Margaret of Navarre, Joan's aunt. Thus by the early fourteenth century, the dukes of Lorraine were connected to both France and Navarre. They also, like many in the region, possessed a history of crusading enthusiasm. ${ }^{56}$ Furthermore, the manuscript clearly glorifies Godfrey of Bouillon, and Godfrey held the duchy of Lower Lorraine until his death in 1100. However, it is exceedingly difficult to explain the presence of the English arms on folio 1 if the manuscript was intended for the dukes of Lorraine. Both Frederick IV (r. 1312-29) and his son Rudolph (or Raoul, r. 1329-46) fought against the English; Rudolph was killed at the Battle of Crecy in $1346 .{ }^{57}$

${ }^{55}$ Christopher Tyerman, 'Philip VI.' For a discussion of Philip IV's 'grante feste' of 1313, an event heavily imbued with crusading overtones and involving many noble families, see Elizabeth A. R. Brown and Nancy F. Regalado, 'La grant feste: Philip the Fair's Celebration of the Knighting of his Sons in Paris at Pentecost of 1313,' in City and Spectacle in Medieval Europe, ed. Barbara Hanawalt and Kathryn Reyerson (Minneapolis: University of Minnesota Press, 1994), 56-86. For a discussion of crusading traditions in French noble families in the twelfth and thirteenth centuries, see Nicholas Paul, To Follow in their Footsteps: The Crusades and Family Memory in the High Middle Ages (Ithaca NY: Cornell University Press, 2012).

${ }^{56}$ Michel Parisse, 'Des Lorrains en croisade. La maison de Bar,' in Chemins d'outremer: Études d'histoire sur la Méditerranée médiévale offertes à Michel Balard (Paris: Publications de la Sorbonne, 2004), 661-70.

${ }^{57}$ E. A Begin, Histoire des Duches de Lorraine et de Bar et des Trois Évècheés (Meurthe, Meuse, Moselle, Vosges), vol. I-II (1833; repr., Geneva: Slatkine-Megariotis Reprints, 1975), 205. 
There were other regional families with links to England, France, Navarre, and Lorraine. To highlight just one such family, the counts of Bar had a tradition of crusading that went back to the First Crusade. ${ }^{58}$ Indeed, it appears to have been a family tradition to die on crusade, a tradition still flourishing in the early fourteenth century. Count Henry III of Bar (r. 1291-1302) departed on crusade to Cyprus in 1302, but wound up in service to the Sicilian Angevins and died in Naples in September 1302. ${ }^{59}$ In 1336 his son, Edward I of Bar (r. 1302-36), departed on crusade in response to Philip VI's crusade plans and the announcement of crusade indulgences by Pope Benedict XII that same year. ${ }^{60}$ He died near Famagusta, Cyprus, en route to crusade. ${ }^{61}$ At the time Edward possessed relatively close ties with Lorraine, England, and France: Edward's maternal grandfather and namesake was Edward I of England, who had been influential during Edward's minority; ${ }^{62}$ his relations with the Valois were good; ${ }^{63}$ and Bar and Lorraine fought together in the conflicts with Metz from 1324 onwards. ${ }^{64}$ The Bar/Lorraine relationship was

${ }^{58}$ Members of the comital house participated in (and died on) the First, Second, Third, Fourth, and Fifth Crusades, and were known as crusade leaders who traced their lineage back to Godfrey of Bouillon. See Parisse, 'Des Lorrains en croisade.'

${ }^{59}$ Georges Poull, La Maison souveraine et ducale de Bar (Nancy: Presses Universitaires de Nancy, 1994), 257.

${ }^{60}$ Poull, La Maison souveraine, 290.

${ }^{61}$ Poull, La Maison souveraine, 286.

${ }^{62}$ Poull, La Maison souveraine, 260-2. On the administration of the county during Edward I's reign, see Hubert Collin, 'Le Comté de Bar au debut du XIV ${ }^{\mathrm{e}}$ siècle: Étude de géographie administrative et économique,' Bulletin philologique et historique (1971): 81-93.

${ }^{63}$ Poull, La Maison souveraine, 265.

${ }^{64}$ Poull, La Maison souveraine, 262-4. Of course, this was after years of warfare between Bar and Lorraine; it is fair to say that over the long term, all of these relationships tipped from conflict to alliance, and vice versa. 
further affirmed in 1329 when Eleanor, Edward's daughter, wed Rudolph of Lorraine. ${ }^{65}$ Thus in the early to mid-1330s, Edward I of Bar was on relatively good terms with both the French and English thrones and Lorraine, as well as indirectly with Navarre through connections with the Valois and Lorraine.

The circumstances of Edward I of Bar's life do not prove that the manuscript was intended for his household, but rather demonstrate that while there are obstacles to arguments for a royal or ducal audience, there are alternative noble patrons for historians to consider. It seems more likely that fr. 352 was intended for a substantial noble household linked to multiple regional powers - like that of Edward I of Bar, if not his specifically — than for royal or ducal consumption. This may have been in the 1330s, when a crusading venture involving France, England, Navarre, and Lorraine was a real possibility. Alternatively it may have been circa 1350 as Folda suggested, a time when confidence in the French monarchy's ability to organize and lead a major crusade was at a low ebb, although equally crusade enthusiasm among the French nobility remained in place, given the response to the crusade initiated by Peter I of Lusignan (r. 1358-1369) in the $1360 \mathrm{~s}^{66}$ In that context, we might read the four coats of arms-all the same size and in parallel positions — on folio 1r as nostalgia for the multinational crusade ambitions left to wither on the vine in previous decades.

\footnotetext{
${ }^{65}$ Begin, Histoire des Duches, 195. She died just three years later. Edward's heir (Henry IV of Bar) and Rudolph of Lorraine came into conflict in 1337; the intervention of Philip VI in 1338 renewed the peace (Georges Poull, La Maison decale de Lorraine devenue La Maison impériale et royale d'Autriche, de Hongrie et de Bohême (Nancy: Presses Universitaires de Nancy, 1991), 108).

${ }^{66}$ See Housley, The Later Crusades, 38-43.
} 


\section{Analysis of the manuscript's miniatures}

One of the most impressive features of fr. 352 is the concentrated grouping of miniatures surrounding events at Antioch in 1098. A striking group of twelve column miniatures depict eleven crusade leaders leading their men to battle, with a final twelfth miniature claiming to depict the whole army. ${ }^{67}$ Each of these miniatures is identical in terms of layout: armed knights on horseback, equipped with banners and led by foot soldiers, exit the gate of Antioch from left to right and are blessed by God in heaven (Figure 1). The knights are identified by rubrics and distinct coats of arms depicted on shields and banners. The final such miniature showing 'toute l'ost' depicts a group of knights riding out together with four different banners, including those of Godfrey of Bouillon, Tancred, and Robert of Flanders as represented in earlier miniatures. After these twelve column miniatures, a panel miniature shows the battle between crusaders and the besieging Turks outside Antioch.

This cluster of miniatures around Antioch is extraordinary. How should we interpret it? First, the arms depicted in fr. 352 are not historically accurate; coats of arms only developed in the early twelfth century. Rather, as Mark Cruse has explained, such a depiction of arms in a later medieval manuscript served to emphasize the most important individuals and to allow the audience to visually identify said individuals in different miniatures. ${ }^{68}$ We see this in the cluster of miniatures surrounding Antioch. The twelve column miniatures outline key personages of the First Crusade in painstaking detail, one by one. The images introduce these men and their purported arms to the viewer much as participants at a tournament would have paraded before

${ }^{67}$ Fols. 47v, 48r, 48v, 49r.

${ }^{68}$ Mark Cruse, 'Costuming the Past: Heraldry in Illustrations of the 'Roman d'Alexandre' (Oxford, Bodleian Library, MS Bodley 264),' Gesta 45, no. 1 (2006): 45-8. As Cruse has noted, this use of arms within manuscripts is a powerful development dating from the late thirteenth century onwards (44). See also Leson, 'Chivalry and Alterity.' 
their audience. ${ }^{69}$ Making sure the viewer could recognize each coat of arms was necessary so that subsequent miniatures could employ said coats of arms, thus allowing continued identification of the key figures even without elaboration in rubrics or text. Because of the first eleven column miniatures surrounding the Battle of Antioch in fr. 352, we are able to 'see' the identity of key players in the larger and more complicated panel miniatures of the Battle of Antioch and the Conquest of Jerusalem (Figure 3); Robert of Flanders, Tancred of Sicily, and others are led by Godfrey of Bouillon in the former, while Robert of Normandy, Robert of Flanders, Tancred of Sicily, Hugh of St. Pol, and others are led by Godfrey of Bouillon in the latter. ${ }^{70}$ At the same time, the twelfth column miniature depicting 'toute l'ost' (as well as the other, apparently random, arms depicted in the miniatures) ensures we recognize the importance of unity on the First Crusade. There were prominent individuals, with loyal contingents, yet they acted together and alongside anonymous others when on crusade.

Second, again as Cruse has observed, making ancient warriors resemble contemporary figures (complete with arms) and constructing ancient battles as contemporary jousts erases 'the distance between past and present, viewer and image. ${ }^{71}$ This in essence creates an 'idealizing mirror ${ }^{72}$ that both commemorates the past and glorifies the present. As Cruse explains, such a mirror conveyed both moral and narrative resemblance between past and present. ${ }^{73}$ Given the

${ }^{69}$ For more on the correlation between heraldry in tournaments and in illuminations, see Cruse,

'Costuming the Past' and Leson, 'Chivalry and Alterity.'

${ }^{70}$ This parallels the way that the text of the Eracles repeatedly highlights the participation of crusade leaders by name.

${ }^{71}$ Cruse, 'Costuming the Past,' 51-2.

${ }^{72}$ Cruse, 'Costuming the Past,' 52.

${ }^{73}$ Ibid. There is a clear correlation between the way this kind of imagery seems to have functioned and the way vernacular prose historiography itself functioned in thirteenth-century noble French society (Spiegel, Romancing the Past). 
enthusiasm for crusading in Philip VI's court and, later, in response to the appeals of Peter I of Lusignan, in fr. 352 this resemblance may have served to encourage and justify crusading endeavours.

Why emphasize such a resemblance between crusading past and chivalric present at Antioch, rather than at Jerusalem? To start, we must acknowledge the intense narrative power of events at Antioch in 1097-98, which were often seen as a pivotal crisis and turning point for the First Crusade. The inherent drama of those events meant that not only most Latin chronicles of the First Crusade but also a rich and popular vernacular tradition in France and environsincluding the Eracles, the Chanson d'Antioche, and the Canso d'Antioca-emphasized Antioch. But a further reason can be seen in the illumination program of fr. 352 in particular. In fr. 352, the conquest of Jerusalem serves to mirror another, even earlier, event: the Passion of Christ.

As noted, unlike all other manuscripts in its group (per Folda), fr. 352 begins with a dramatic, half-page panel miniature (Figure 2). The city of Jerusalem takes up most of the centre and right of the miniature, with the stages of the Passion depicted prominently near the top of the image in sequence from left to right: arrest, flagellation, carrying the cross, crucifixion, and placement in the tomb. Each stage is contained within a lateral chapel arcade surmounted with a pointed, trefoil arch, within a rectangular building that strongly resembles a Gothic structure with buttresses. Three towers of the city break the frame; otherwise the image is contained within its frame. In the upper left the Ascension is depicted outside the city walls, while in the lower left we see the Dormition of the Virgin. The miniature is coloured; primarily blue-grey and red/russet for everything from roofs and building stones to articles of clothing, along with some yellow and taupe, and green for foliage. Gilding highlights the buildings housing the Passion and the Dormition of the Virgin, the city gates, and haloes. 
Folio 62r also contains a half-page coloured and gilded panel miniature showing Jerusalem (Figure 3). The majority of the frame is filled with the city of Jerusalem, depicted with towers, walls, and a half-open portcullis. Just as on folio 1r, the stages of the Passion are in sequence from left to right within a rectangular building that again strongly resembles a Gothic structure. Siege equipment, including a wheeled siege tower and trebuchet, is visible on the lower right. The crusaders are shown moving from lower left to middle right on an upwards diagonal track. Godfrey of Bouillon and his men are in the lead, followed by other prominent crusaders and their contingents: Robert of Normandy, Robert of Flanders, Tancred of Sicily, and Hugh of St. Pol. They are climbing a ladder onto the wheeled siege tower and passing from there onto the walls of the city; almost all of their spears and banners are angled towards the upper right. In the lower right corner, other crusaders attend to the trebuchet; stones seem to be hanging in mid-air en route to the city walls. Meanwhile, just as on folio 1r, outside the city the Ascension of Christ and Dormition of the Virgin are shown. The miniature is contained within the frame with the exception of one tower that breaks the upper border at the far right. The basde-page illumination shows a hound chasing a rabbit or hare from right to left. The colours in the miniature are the same as in folio 1r, with the addition of prominent white tents. Compared with folio $1 \mathrm{r}$, there is additional gilding on the siege tower and trebuchet, as well as some elements of the crusaders' clothing, weapons, and banners. Also, in folio $62 \mathrm{r}$ the background to the flagellation of Christ is fully gilded and the background to Christ carrying the cross is a vivid crimson; in folio 1r both backgrounds are more sombre. As noted, there are no Muslims depicted in folio 62r; the First Crusaders storm a city empty except for the Passion.

One glance reveals that the half-page illuminations on folios $1 \mathrm{r}$ and $62 \mathrm{r}$ are virtually identical. The primary differences are the bird, monkey, and coats of arms on folio 1r and the 
presence of crusaders and siege equipment on folio 62r. Less importantly, on folio 62r only one tower in the city (instead of three) breaks the frame, the borders on folio $1 \mathrm{r}$ are more extensive, and though both folios have bas-de-page illuminations inspired by hunting, the depicted prey is different (a stag on folio 1r, a rabbit or hare on folio 62r). The similarity between the two miniatures is extraordinary and demands our attention. How should we interpret folio $62 \mathrm{r}$ in light of this dramatic and intentional resemblance?

Even taken on its own-i.e., without comparison to folio $1 \mathrm{r}$ - folio $62 \mathrm{r}$ collapses the historical distance between the Passion and Resurrection of Christ and the First Crusade. This is clearly deliberate. The image draws the eye to the city of Jerusalem and, within the city, to the Passion itself. In addition, the image lends Christ and the crusaders parallel movement and trajectory. The stages of the Passion move from left to right, each bound by an architectural frame and together bound by the city walls of Jerusalem itself. At the same time, the crusaders also move from left to right and from the ground up to the level of the city walls. The line of the Passion is roughly horizontal, while that of the crusaders is diagonal; the two lines are set to intersect at the far right of the image (or, indeed, just to the right of the image, outside the frame). The sense that the Passion and the crusaders are moving in the same direction-the direction of reading, and thus of time- - is further enhanced by the fact that the face of Christ in the first three Passion panels and the faces and weapons of the crusaders are inclined to the right. Similarly, the one tower that breaks the frame is located at the far right edge of the image, drawing our attention and perhaps visually suggesting that this particular tower is somehow closer to the viewer than the rest of the city, pulling the viewer towards the moment when the Passion and the crusaders will intersect. 
It is not surprising that the image represents the Passion and the assault on Jerusalem as cotemporaneous; one need look no further than traditional accounts of the First Crusade to see the same idea presented in words ${ }^{74}$ Presumably, a viewer of the manuscript would have had a pre-existing awareness of the fact that Jerusalem was, literally, common ground for the Passion and the First Crusade. I have just noted that even taken as a stand-alone image, folio 62r places the Passion and the First Crusade within the same temporal—and literal—frame. The fact that folio $62 \mathrm{r}$ is essentially folio $1 \mathrm{r}$ plus crusaders makes the point even more explicit: Jerusalem was where both the Passion of Christ and the First Crusade took place. Chronological distance that may seem pressing to modern minds appears irrelevant in fr. 352 in light of this shared location. But there is another layer of mirroring at work-the mirrored motion from left to right. In folio $1 \mathrm{r}$ the stages of the Passion move from left to right, while in folio $62 \mathrm{r}$ both the stages of the Passion and the crusaders move from left to right on an intersecting course. Again, that folio $62 \mathrm{r}$ is folio 1r plus crusaders confirms this parallel movement: as the Passion proceeded, so the crusaders proceeded. Again, the centuries between the Passion and the First Crusade are collapsed within the manuscript's illuminations; they are irrelevant in light of this shared action.

Yet at the same time that the relationship between folios $1 \mathrm{r}$ and $62 \mathrm{r}$ appears to collapse time, it also underscores time's passage through their respective places in the manuscript. It seems reasonable to assume that a viewer would have moved through the manuscript in order, seeing first the Passion alone in folio $1 \mathrm{r}$ and then, rather later, seeing the Passion and the Conquest of Jerusalem in folio 62r. This, then, is a narrative sequence, and it is in chronological

\footnotetext{
${ }^{74}$ For two classic examples, see Baldric of Bourgueil, Historia Jerosolimitana, Recueil des Historiens des Croisades, Historiens Occidentaux 4 (Paris: Académie des inscriptions et belles-lettres, 1879), 101-2 and William of Tyre, Chronicon, ed. R. B. C. Huygens, Corpus Christianorum, Continuatio Mediaevalis 63, 2 vols. (Turnhout: Brepols, 1986), 1:410.
} 
order. Even if, as seems likely, viewers also flipped back to folio 1r from 62r, nonetheless the placement of folios 1r and 62r ensures that that movement backwards in the manuscript would have paralleled a movement backwards in time. Thus, somewhat paradoxically, at the same time that the images of folios $1 \mathrm{r}$ and $62 \mathrm{r}$ relegate chronological distance to the background, the very fact that they are 61 folios apart emphasizes it. To put it another way, if folio $62 \mathrm{r}$ on its own asserts 'just as Christ, so too the First Crusaders,' then the sequence of folio 1r and 62r asserts 'just as first Christ, so too then the First Crusaders.'

In addition to conveying a sense of historicity, the sequence may have implied causality. There are in fact a number of ways to make sense of that causality for a mid-fourteenth-century audience. Medieval contemporaries wrote at length about the effects of the Passion on Christian history, and also on the effect of viewing or meditating upon the Passion; ${ }^{75}$ following their lead, modern scholars have also written at length on medieval views of these topics. ${ }^{76}$ What is most

\footnotetext{
${ }^{75}$ Most famously, the Meditationes Vitae Christi: Meditations on the Life of Christ: An Illustrated Manuscript of the Fourteenth Century, ed. Isa Ragusa and Rosalie B. Green (Princeton: Princeton University Press, 1961).

${ }^{76}$ Sara Lipton, “The Sweet Lean of His Head': Writing about Looking at the Crucifix in the High Middle Ages,' Speculum 80, no. 4 (2005): 1172-1208; Rachel Fulton, From Judgment to Passion: Devotion to Christ and the Virgin Mary, 800-1200 (New York: Columbia University Press, 2003); Alasdair A. Macdonald, H. N. Bernhard Ridderbos, and R. M. Schlusemann, eds., The Broken Body: Passion Devotion in Late-Medieval Culture (Groningen: Egbert Forsten, 1998); Ellen M. Ross, The Grief of God: Images of the Suffering Jesus in Late Medieval England (Oxford: Oxford University Press, 1997); Richard Viladesau, The Beauty of the Cross: The Passion of Christ in Theology and the Arts, from the Catacombs to the Eve of the Renaissance (Oxford: Oxford University Press, 2006); Robert Worth Frank, Jr., 'Meditationes Vitae Christi: The Logistics of Access to Divinity,' in Hermeneutics and Medieval Culture, ed. Patrick J. Gallacher and Helen Damico (Albany: State University of New York Press, 1989), 39-50; Jeffrey Hamburger, 'The Visual and the Visionary: The Image in Late Medieval Monastic Devotions,' Viator 20 (1989): 161-82; Cynthia Hahn, 'Purification, Sacred Action, and the Vision of God: Viewing Medieval Narratives,' Word \& Image 5 (1989): 71-84.
} 
relevant for our purposes is that by the later Middle Ages, viewing or meditating on the Passion, the ultimate expression of God's love ${ }^{77}$ was believed to have specific effects on a Christian. First, the individual would feel compassion for Christ's suffering, followed by reflection on his/her own role in causing that suffering. This reflection would be followed by contrition, confession, and finally the resolution to do better — to avoid sin, but going even further, to live according to the precepts of caritas, Christian love for one's neighbour. ${ }^{78}$ Thus Passion devotion provoked both an intellectual and affective response, and could function as mediation, portal, or confirmation of a personal relationship between God and humanity. Yet it also drove Christians to take action in order to follow Christ's example; to embrace the ideal of the imitatio Christi. ${ }^{79}$ If we accept that for many, crusading was a spiritual enterprise that was deeply linked both to the imitatio Christi ${ }^{80}$ and to the concept of caritas, ${ }^{81}$ then it is plausible to read implied causality into

${ }^{77}$ As Peter Lombard expressed it in the twelfth century, in the crucifixion 'we are shown a sign of such love that we are moved and enflamed to the love of God, who did so much for us' (Peter Lombard, Sententiae in IV Libris Distinctae, bk. 4, dist. 19, cited by Viladesau, Beauty of the Cross, 91).

${ }^{78}$ Ross, Grief of God, 24-5.

${ }^{79}$ Ross, Grief of God, 45; R. N. Swanson, 'Passion and Practice: The Social and Ecclesiastical Implications of Passion Devotion in the Late Middle Ages,' in The Broken Body: Passion Devotion in Late-Medieval Culture, ed. A. A. Macdonald, H. N. B. Ridderbos, and R. M. Schlusemann (Groningen: Egbert Forsten, 1998), 1-30. Swanson discusses a powerful image from Rome, Biblioteca Casanatense, MS 1404, fol. 37v (12-13). The image shows a man engaged in three stages of response to the Cruficixion: carrying the cross (imitatio), suffering the stigmata (conformatio) and kissing Christ's feet (devotio).

${ }^{80}$ Most recently, William Purkis, Crusading Spirituality in the Holy Land and Iberia, c. 1095-c. 1187 (Woodbridge: Boydell and Brewer, 2008).

${ }^{81}$ Jonathan Riley-Smith, 'Crusading as an Act of Love,' History 65 (1980): 177-92; Susanna A. Throop, 'Acts of Vengeance, Acts of Love: Crusading Violence in the Twelfth Century,' in War and Literature, ed. Laura Ashe and Ian Patterson, Essays \& Studies 2014 (Woodbridge: Boydell \& Brewer, 2014), 3-20. 
the relationship between folios $1 \mathrm{r}$ and $62 \mathrm{r}$. The implication may have been that devotion to the Passion prompted crusading as an act of caritas and the imitatio Christi. Indeed, this message was explicitly driven home in a number of crusade sermons in the thirteenth and early fourteenth centuries. As Eudes of Châteauroux wrote, 'it is a sign that a man loves God, when he rejects the world. Thus it is a manifest sign that a man burns with love and zeal for God, if he goes across the sea in the service of Jesus Christ, abandoning fatherland, possessions, homes, sons, and wives for God. ${ }^{82}$ Even more vividly, Gilbert of Tournai hoped that his audience would 'bear [Christ's] stigmata on your body, so that, offering a burnt sacrifice within, you may have his skin on the outside. For it ought to be that he who says he remains in Christ through internal love should himself walk as he [Christ] walked, in open imitation of his deeds and passion. ${ }^{83}$

The presence of this kind of crusading devotion in folio $62 \mathrm{r}$ is confirmed by the close physical parallels between Christ and the crusaders. As noted, both the crusaders and Christ face to the right, and 'move' to the right as well. Going further, the image appears to construct a 'cross' from the crusaders and their accoutrements: one arm of the cross is formed by the trebuchet's beam and a single crusader banner pointing diagonally up to the left, while the other arm is formed by the line of the crusaders - and their banners - moving from the ground up to the city gates on the right. The angles of this 'cross' mirror the angles of Christ's cross as he is carrying it in the gothic structure above. Finally, the scenes of the flagellation and carrying the cross are highlighted by, respectively, gilded and crimson backgrounds; the arms of the crusaders are, with one exception, yellow and red, again suggesting that the crusaders are mirroring Christ's passion.

\footnotetext{
${ }^{82}$ Eudes of Châteauroux, 'Sermo 1,' in Crusade Propaganda and Ideology, 130-2.

${ }^{83}$ Gilbert of Tournai, 'Sermo 1,' 184-6.
} 
Admittedly, there is an alternative narrative that also could have enabled a causal understanding. Viewing or dramatizing the Passion at times led to anger and outrage against those deemed guilty of Christ's death, whether in a crusading context or not. The link between Passion devotion and anti-Jewish violence is well-established, ${ }^{84}$ and popular narratives of vengeance for the Passion were widespread in the later Middle Ages. ${ }^{85}$ Furthermore, the idea of crusading as an act of vengeance was perfectly compatible with the idea that crusading was a spiritual enterprise. ${ }^{86}$ This idea visibly evolved and acquired momentum in the course of the first century of crusading, appearing much more frequently in later texts than in earlier accounts. Although no one has studied the idea of crusading as an act of vengeance in detail after 1216, at the very least we can say that it survived into the fourteenth century. ${ }^{87}$

${ }^{84}$ There is extensive scholarship on this point. An accessible synthesis of key points can be found in Jeremy Cohen, Christ Killers: The Jews and the Passion from the Bible to the Big Screen (Oxford: Oxford University Press, 2007). A recent discussion of the link between changing representations of Christ and attitudes towards Jews is Janez Premk, 'The New Iconography of Christ and the Changes in Depictions of the Jews in High and Late Middle Ages,' Ikon 1 (2008): 157-68.

${ }^{85}$ The development of Passion plays with strong anti-Jewish overtones is well-known; I also refer to legendary accounts of the conquest of Jerusalem by Titus and Vespasian (Vindicta salvatoris/Venjance de nostre seigneur). See Alvin E. Ford, ed., La Vengeance de Nostre-Seigneur: The Old and Middle French Prose Versions, 2 vols. (Toronto: University of Toronto Press, 198493); Stephen K. Wright, The Vengeance of Our Lord: Medieval Dramatizations of the Destruction of Jerusalem (Toronto: University of Toronto Press, 1989). For a broader study of overall trends, see Miri Rubin, Gentile Tales: The Narrative Assault on Late Medieval Jews (New Haven: Yale University Press, 1999).

${ }^{86}$ See Throop, Crusading as an Act of Vengeance, passim but esp. 97-114, 135-9.

${ }^{87}$ To give just one example, several accounts and letters from the early fourteenth century discussing the imaginary Mongol conquest of Jerusalem either ascribe a desire for vengeance to God, to khān Ghazan, or to both. Sylvia Schein, 'Gesta Dei per Mongolos 1300: The Genesis of a Non-Event,' The English Historical Review 94 (1979): 806, 816, 819. 
Some texts supported the idea of crusading as vengeance with a Jerusalem-centric narrative asserting that the Jews had wrongly killed Christ (in Jerusalem), the Muslims were oppressing Christianity and threatening conquest (in Jerusalem), and crusaders were seeking vengeance (in Jerusalem). Indeed, some of the texts incorporated Muslims into the Christian historical narrative alongside the Jews, thus making them responsible for the crime of the crucifixion. ${ }^{88}$ The urgency of this narrative was intensified in the texts by a rhetorical emphasis on injuries to Christ and the immediacy of crucifixion descriptions; it was not unusual for the crucifixion to be described in the present tense-and deserving vengeance as a result. Fr. 352 could be said to likewise present the crucifixion in the present tense, so to speak, and to present a visualization of a Jerusalem-centric narrative of vengeance.

At this point some may wonder whether the textual evidence sheds any light on the illumination program in fr. 352. Of course, it is now commonly understood that manuscript illuminations are not 'illustrations' of manuscript text. Indeed it is not unusual for illuminations to complicate or even directly contradict text. In this case, however, the textual descriptions of the First Crusade and the conquest of Jerusalem in the Old French Eracles contain evidence both for the idea of crusading as an act of vengeance and for the imitatio Christi. For example, the Eracles states that after Pope Urban II's appeal, many took the cross because 'il sembloit que chascuns déust sur soi prendre tous seus a vengier le tort et la honte que li Mescréant fesoient à Nostre Seigneur et à son pueple en sa terre de Jherusalem. ${ }^{, 89}$ Yet a little further on, after

${ }^{88}$ Similar correlations between the crucifixion, crusading to Jerusalem, and anti-Jewish sentiment can be seen in twelfth-century visual evidence, too. For example, see Naomi R. Kline, 'The Typological Window of Orbais-l'Abbaye: The Context of its Iconography,' Studies in Iconography 14 (1995): 83-130.

${ }^{89}$ Guillaume de Tyr et ses continuateurs, 30 (bk. 1, ch. 16). Nothing similar to this sentence is present in this section of the Latin chronicle of William of Tyre; see William of Tyre, Chronicon, 1:136. In 
representing the idea that the expedition would be an act of vengeance, the Eracles supports the idea of crusading as the imitatio Christi, explaining that Urban established

... que tuit cil qui à ce pelerinage se lioient, mettoient le signe de la croiz sur la destre espaule, por l'enneur de celui qui le torment de la croiz porta à ses espaules por nous sauver; et accomplissoient ce que Jhesucrist dist en l'Evangile: Qui vent venir après moi, renie noi meismes, et preigne la crois et me suive. ${ }^{90}$

Both ideas of crusading_-vengeance and imitatio Christi-are also reflected in descriptions of the conquest of Jerusalem. The Eracles describes pre-battle processions around the city of Jerusalem, and explains that during said processions, the inhabitants of the city hung a cross upon the walls and mocked and defiled it; seeing this, the crusaders 'mout leur en croissoit en leur cuers li desirriers de vengier la honte Jhesu-Crist. ${ }^{91}$ This seems to suggest that the conquest of Jerusalem was a pursuit of vengeance. Yet, after describing the successful conquest of the walls of Jerusalem, the Eracles notes the synchronicity of the Passion and the conquest of Jerusalem:

contrast, William of Tyre explicitly describes Pope Eugenius III's call for the Second Crusade in terms of vengeance; see William of Tyre, Chronicon, 2:739-40.

${ }^{90}$ Guillaume de Tyr et ses continuateurs, 31 (bk. 1, ch. 16). Cf. the Latin chronicle: 'Convenerat autem apud omnes, et idipsum de mandato domini pape iniunctum fuerat, ut quotquot predicte vie voto se obligarent, vivifice crucis salutare signum vestibus imprimerent et in humeris illius sibi portarent memoriam, cuius passionis locum visitare proposuerant, illum imitantes, cui ad nostrum redemptionem properanti factus est ... et illud domini mandatum iuxta litteram plane videbatur impleri: qui vult venire post me, abneget semet ipsum et tollat crucem suam et sequatur me' (William of Tyre, Chronicon, 1:137-8).

${ }^{91}$ Guillaume de Tyr et ses continuateurs, 279 (bk. 8, ch. 11). References to vengeance are not present in the parallel passage in the Latin chronicle: ' ... populus tamen cum omni devotione votum prosequens, ira succensus qualem sacrilegii dolor poterat ministrare, ad predictam pervenit ecclesiam' (William of Tyre, Chronicon, 1:401). 
Ce fut le jor d'un vendredi, entor none. Bien est créable chose que Nostre Sires le fist par grant senefiance: car à ce jor, entor cele eure, soufri-il mort en ce leu por les pecheurs raembre. A ce jor meismes fu fez li premerains homs; pour ce vout-il, li haus Sires, que li pueples de ses pelerins leaus à tel jor li rendist sa ville et delivrast, à son servise fere, et rendist la franchise aus crestiens qui longuement i avoient esté en dolereus servage. ${ }^{92}$

Thus the text of the Old French Eracles appears to support the idea that both the imitatio Christi and the idea of crusading as an act of vengeance may be present in the manuscript's images.

However, in the end, it is difficult to identify a visual representation of the idea of crusading as vengeance in folio 62r. Admittedly, this is in part because it is hard to identify precisely how 'crusading as an act of vengeance' would be visually represented in the first place. Yet there are no Muslims in the city of Jerusalem, on which vengeance might be taken, and while two Jews are shown scourging Christ, they are not overtly demonized. Indeed, the figure of Christ is shown relatively free of distress and unscathed; his head tilts down and eyes are shut on the cross, indicating death, but there are no visible wounds or bloodshed, which might require vengeance. Given this, and given the clear ways already discussed in which the crusaders are shown to mirror Christ, the visual evidence most supports the idea that in folio $62 \mathrm{r}$, we see the First Crusaders engaged in the imitatio Christi. This does not eliminate the possibility that the manuscript's contemporary audience may have seen vengeance in the image, but it suggests that they would have done so based on the text or their own prior ideas about crusading, rather than because of the manuscript's illuminations.

${ }^{92}$ Guillaume de Tyr et ses continuateurs, 289 ( bk. 8, ch. 18). Cf. the Latin chronicle: 'Erat autem feria sexta et hora nona, videturque procuratum divinitus, ut qua die et qua hora pro mundi salute in eadem urbe passus est dominus, eadem et pro Salvatoris gloria fidelis decertans populus desiderii sui felicem impetraret consummationem: eadem enim die et primus homo conditus et secundus pro primi salute morti traditus esse legitur, unde et decuit ut eius membra et imitatores in ipsius nomine de hostibus eiusdem triumpharent' (William of Tyre, Chronicon, 1:410). 
The mirroring just discussed between the Passion and the First Crusaders is not the only 'mirroring' visible in folios $1 \mathrm{r}$ and 62r, however. In both panel miniatures, the Passion occurs within architectural structures in the city of Jerusalem. Dominating the city of Jerusalem is a Gothic structure, long and rectangular, with flying buttresses. The stages of the Passion are contained within five arcades; each arcade is surmounted with a trefoil motif and pointed arch topped with a finial. At the left of these arcades is a taller apse with two vertical segments surmounted by a circular window, a trefoil motif, and a pointed arch topped with a finial. As Folda notes, this is all most unusual. ${ }^{93}$

It is also different from the kind of architectural elements commonly used to frame illuminations. As Harvey Stahl thoughtfully explains, there is a long history of medieval illuminations framing figures and narratives within architectural elements. Several functions were played by such framing: mediating between viewer and image, defining and structuring the image, and linking action and background. In addition, such framing linked illuminations with other elements of visual religious culture, specifically cathedrals and reliquaries; many Gothic cathedrals possessed figures and narratives surrounded by architectural framing, and starting in the mid-thirteenth century, reliquaries were sometimes made to resemble Gothic structures. ${ }^{94}$ Of course, the Holy Sepulchre itself compartmentalized the stages of the Passion into discrete, bounded areas.

The Gothic structure in folios $1 \mathrm{r}$ and $62 \mathrm{r}$ is indeed serving many of these same framing functions. Yet, in contrast with the kinds of framing that Stahl outlines (as visible in the Psalter of Saint Louis, for example), the Gothic structure in folios $1 \mathrm{r}$ and 62r is depicted as an actual

\footnotetext{
${ }^{93}$ Folda, 'The Illustrations in Manuscripts,' 1:424.

${ }^{94}$ Harvey Stahl, Picturing Kingship: History and Painting in the Psalter of Saint Louis (University Park, PA: Penn State U. Press, 2008), 83-9.
} 
building in an actual city, embedded within its surroundings. At the same time, although the actual Holy Sepulchre in Jerusalem does compartmentalize the stages of the Passion, it assuredly does not resemble the building in folios $1 \mathrm{r}$ and 62r. Why present the stages of the Passion in this way? In her discussion of geographically indeterminate representations of the Levant in manuscript illuminations, Maureen Quigley has rightly emphasized that such 'inaccurate' representations did not result from ignorance. Rather, she argues, they emphasized action over topography, creating an 'experiential geography in which personal experience is emphasized over location. 95 This helped viewers to imagine their own actions upon arrival in the distant location. ${ }^{96}$ Of course, unlike the images Quigley has analysed, the building depicted in folios $1 \mathrm{r}$ and $62 \mathrm{r}$ is not an indeterminate or vague representation; the oddity lies instead in the specific, almost over-determined nature of the misrepresentation.

The answer, I suggest, lies in the physical environs of Paris in the early fourteenth century. Saint Louis IX of France (r. 1226-70) explicitly created the palace chapel and shrine of Sainte-Chapelle, dedicated April 26, 1248, to house recently acquired relics of the Passion, including among others the Crown of Thorns and pieces of the True Cross. The chapel consisted of four rectangular bays, a polygonal apse with seven segments on the east, and a porch on the west. Its architecture invoked 'strong associations both to the church and to the Capetian dynasty' and also resembled the crusader 'Templum Salomonis' (actually the Aqsa Mosque) in Jerusalem. ${ }^{97}$ The two floors of the chapel were separate and the upper chapel connected directly to the royal apartments. In the upper chapel, each bay contained three groups of pointed arches

\footnotetext{
${ }^{95}$ Quigley, 'Romantic Geography,' 54-5.

${ }^{96}$ Ibid., 76.

${ }^{97}$ Daniel H. Weiss, Art and Crusade in the Age of Saint Louis (Cambridge: Cambridge University Press, 1998), 29, 56-65.
} 
enclosing pairs of rounded trefoil arches surmounted by painted quatrefoils. The interior of the upper chapel—where the relics of the Passion were housed—was a 'dazzling wall' of stained glass accompanied by multiple other forms of decoration. ${ }^{98}$ In essence, the upper chapel was a walk-in reliquary. ${ }^{99}$ This was not simply for a private royal audience; Meredith Cohen has convincingly demonstrated public attendance and engagement with Sainte-Chapelle. ${ }^{100}$

As Daniel Weiss has explained, the dedication of Sainte-Chapelle "not only marked the completion of a repository worthy of the sacred relics of the Passion but also consecrated a new locus sanctus. ${ }^{101}$ Sainte-Chapelle communicated that 'Paris had become a new Holy Land' and the French monarchs were its guardians and protectors; in the words of Joseph Strayer and others, it also communicated the 'religion of monarchy." ${ }^{102}$ As Gautier Cornut, archbishop of Sens, noted on the arrival of the Crown of Thorns, 'Just as the Lord Jesus Christ chose the Holy Land to reveal the mysteries of his redemption, so he seems and is believed to have specially chosen our France for the more devoted veneration of the triumph of his Passion. ${ }^{103}$ Indeed, Cohen has argued that Sainte-Chapelle was explicitly designed to be a pilgrimage site. ${ }^{104}$ Even in

${ }^{98}$ Weiss, Art and Crusade, 18. For more on the visual program of the upper chapel, see Alyce A. Jordan, Visualizing Kingship in the Windows of the Sainte-Chapelle (Turnhout: Brepols, 2002). Jordan argues that many of the formal characteristics of the program of stained glass imitate the formal characteristics found in contemporary textual narratives.

${ }^{99}$ Weiss, Art and Crusade, 30.

${ }^{100}$ Meredith Cohen, 'An Indulgence for the Visitor: The Public at the Sainte-Chapelle of Paris,' Speculum 83 (2008): 840-83.

${ }^{101}$ Weiss, Art and Crusade, 11.

${ }^{102}$ Joseph R. Strayer, 'France: The Holy Land, the Chosen People, and the Most Christian King,' in Medieval Statecraft and the Perspectives of History (Princeton: Princeton University Press, 1971), 302. More recently, see Gaposchkin, The Making of Saint Louis, passim but esp. 72-7.

${ }^{103}$ Cited by Weiss, Art and Crusade, 11.

${ }^{104}$ Cohen, 'Indulgence for the Visitor,' 844. 
terms of scale a parallel can be found; while Sainte-Chapelle towered over medieval Paris, ${ }^{105}$ the manuscript building dominates the city of Jerusalem in folios $1 \mathrm{r}$ and $62 \mathrm{r}$.

Admittedly, the building depicted in folios 1r and 62r does not match Sainte-Chapelle in every detail. Sainte-Chapelle has four bays with groups of pointed arches; the manuscript cathedral has five arcades, each topped by a single pointed arch. Sainte-Chapelle has two floors; the manuscript cathedral seems to have only one level. The stained glass in the upper chapel of Sainte-Chapelle is not entirely devoted to the Passion; ${ }^{106}$ Christ does not even wear a Crown of Thorns in the manuscript's Passion scenes. Perhaps most significantly, the manuscript's illumination program does not at all bear witness to the 'religion of monarchy' and the reverence for Louis IX himself so clearly embodied in Sainte-Chapelle. Nonetheless, the visual resonance is strong, and the symbolic weight for a fourteenth-century viewer would surely have been even stronger. ${ }^{107}$ On the one hand, Sainte-Chapelle housed the relics of the Passion; on the other, the manuscript building housed the Passion itself. Sainte-Chapelle reinforced the strong link between the Passion, crusading to the Holy Land, and the French; folios 1r and 62r emphasized the strong link between the Passion, the Holy Land, and the Frankish First Crusaders.

By housing the stages of the Passion within a Sainte-Chapelle-like edifice, folios 1r and 62r eliminate distance and conflate place to emphasize perceived spiritual parallels. The

\footnotetext{
${ }^{105}$ Cohen, 'Indulgence for the Visitor,' 847.

${ }^{106}$ Instead, the glass program presents 'sacred history in images rich in narrative detail with a decided emphasis on holy war and kingship' (Weiss, Art and Crusade, 47).

${ }^{107}$ Richard Krautheimer has argued that medieval viewers understood buildings to be copies of each other in terms other than perfect physical mimicry; instead, what mattered were 'the content and the significance of the building' ('Introduction to an 'Iconography of Medieval Architecture,' Journal of the Warburg and Courtauld Institute 5 (1942): 20).
} 
Jerusalem of the Passion (folio 1r) mirrors the Jerusalem of the First Crusade (folio 62r), and both Jerusalems mirror the architecture of late medieval Paris, ${ }^{108}$ the new Jerusalem.

\section{Conclusions}

This assessment of the manuscript's program of illuminations and argument for a noble rather than royal audience encourages us to view the manuscript and its program of illuminations as a celebration of and encouragement for a deeply-engrained crusading tradition among the nobility in France. This was not, then, a recruitment device aimed at hesitant participants, but rather a presentation of ideas designed to reinforce and celebrate convictions and intentions already in place. It was also a commemoration of the longstanding crusading tradition, a function of memoria, that medieval concept encompassing both the imaginative recall of the past and the equally imaginative evocation of the future. ${ }^{109}$

We can also read fr. 352 as a celebration of regional and family identity. In this light, the manuscript drew upon a proud and illustrious crusading heritage complete with First Crusade heroes, depicted in such extensive detail vis-à-vis Antioch. Through the four coats of arms on folio $1 \mathrm{r}$, the manuscript connected that noble heritage with the major royal houses of early fourteenth-century north-western Europe. In a time dominated by hopes of a multinational

${ }^{108}$ Despite the obvious role played by Sainte-Chapelle in the ideology of later medieval French kingship, the illumination may be reflecting French architecture more broadly as well as Paris specifically. As Weiss demonstrates, in its structural design Saint-Chapelle echoed examples from Europe and France in particular, incorporating 'architectural ideas with strong associations both to the church and to the Capetian dynasty' (Art and Crusade, 29).

${ }^{109}$ There is a helpful and brief discussion of memoria in Nicholas Paul and Suzanne Yeager, 'Introduction: Crusading and the Work of Memory, Past and Present,' in Remembering the Crusades: Myth, Image, and Identity (Baltimore: The Johns Hopkins University Press, 2012), 7-11. The classic work is Mary Carruthers, The Book of Memory: A Study of Memory in Medieval Culture, 2nd ed. (Cambridge: Cambridge University Press, 2008). 
passagium, the value of noble French families whose ranks extended back in time to the First Crusade as well as sideways in the present to different powerful houses (royal and otherwise) must have seemed self-evident, at least to the families themselves.

That fr. 352 is primarily concerned with crusading as an expression of western Christian identity and piety rather than engagement with the 'Other' is strikingly confirmed by its program of illuminations. With their relative absence of Muslims and Jews, especially from depictions of siege and conquest, they suggest that crusading did not always require actual enemies to be a significant and presumably meaningful action. In fr. 352 the importance of crusading rests primarily in what crusading communicates about those who went—and will go—on crusade, not in what it communicates about their opponents.

Finally, we might view the manuscript as a devotional or meditational tool, used by those preparing to depart, or by those remaining at home and seeking a way to envision or mentally participate in the actions of the departed. Indeed, as I have shown, fr. 352 combines chivalric and devotional elements in a striking manner, both in its choice of texts and, especially, in its program of illuminations. In its text, the manuscript combines a description of Christ's life and death in the Holy Land with an abridged history of crusading in the twelfth and thirteenth centuries. In its illuminations, the manuscript both places an extraordinary emphasis on chivalric identity and at the same time constructs a series of spiritual parallels through the placement and design of folios 1r and 62r: parallels between the Passion and the First Crusade; the person of Christ and the First Crusaders; the First Crusaders and contemporary chevaliers; and the city of Jerusalem and fourteenth-century Paris.

Ultimately, rather than representing a window into another time or a different part of the world, the illuminations of fr. 352 represent crusading as a mirror for participants. At a moment 
when they or their close associates were preparing to crusade, fourteenth-century viewers may have tried to see their own or their loved ones' reflection in the manuscript's images of the crusaders marching forth with colourful banners flying at Antioch and Jerusalem. They may have pondered the connection between the Jerusalem that housed the crucifixion of Christ, the Jerusalem sought and won by the First Crusaders, and their own new Jerusalem of Paris. Faced with the indisputable similarity of folios $1 \mathrm{r}$ and $62 \mathrm{r}$, they would have meditated on the way in which crusading imitated, yet also responded to, the Passion, and the way the Passion led to the First Crusade, which perhaps in turn seemed to lead to their own endeavours.

The major implications of this argument for our broader understanding of crusade history are threefold. First, it confirms continuing engagement with crusading — its past, present, and future-among the noble houses of later medieval France. At this point it is indisputable that the French monarchy sought to lay claim to crusading in historiographical and monumental terms and was highly successful in doing so, yet it appears that the crusading tradition among the nobility — a tradition that elided French monarchs and glorified Godfrey of Bouillon insteadremained alive and, if the richness of fr. 352 is any guide, both highly valued and well-funded. ${ }^{110}$ Second, fr. 352 deepens our understanding of the kinds of Christian devotion present in the fourteenth-century crusading movement. For this period, Norman Housley has noted a contrast between chivalric crusade devotion, with an emphasis on providing service to God by bearing arms, and penitential crusade devotion, characterized by the imitatio Christi and reserved primarily for expeditions to the Holy Land. ${ }^{111}$ Without denying Housley's overall point, fr. 352 suggests that both kinds of Christian devotion were at times compatible and represented side by

\footnotetext{
${ }^{110}$ Similar points are made in Housley, The Later Crusades, 393, 395-403.

${ }^{111}$ Ibid., 401.
} 
side; the miniatures surrounding the conquest of Antioch seem to emphatically represent a more chivalric ethos of armed service to God, while folios $1 \mathrm{r}$ and $62 \mathrm{r}$ speak to a thriving commitment to the imitatio Christi. Third, and most obviously, this work has demonstrated the fruitful evidence available in previously under-studied sources. There is surely further insight that can be drawn from fr. 352, and hopefully this piece will encourage other scholars to engage with such relatively unexamined sources in the future.

Table 1: Miniatures and Corresponding Rubrics in Bibliothèque nationale de France, MS fr. 352

\begin{tabular}{|c|c|c|}
\hline Folio & Brief Description of Miniature & Corresponding Rubric \\
\hline $1 \mathrm{r}$ & $\begin{array}{l}\text { Jerusalem with Passion, Ascension, and } \\
\text { Dormition of the Virgin }\end{array}$ & -- \\
\hline $1 \mathrm{v}$ & Raising of Lazarus & du ladre que nostre sires resuscitata \\
\hline $2 \mathrm{r}$ & Nativity & de nativite nostre seigneur \\
\hline $2 \mathrm{v}$ & Annunciation & l'annontiation as pastouriaux \\
\hline $4 \mathrm{v}$ & Epiphany & des III rois \\
\hline $4 \mathrm{v}$ & Presentation at the Temple & ci reçoit saint simeon nostre seigneur \\
\hline $5 \mathrm{v}$ & Jews plotting against Jesus & de l'acusation des juys sour jhesu crist \\
\hline $6 v$ & Crucifixion & -- \\
\hline $10 \mathrm{v}$ & Harrowing of Hell & -- \\
\hline $28 \mathrm{r}$ & $\begin{array}{l}\text { Wife and sons of Qilij Arslan in captivity on a } \\
\text { ship }\end{array}$ & de la fame solimant et ses enfans \\
\hline $29 \mathrm{v}$ & Godfrey of Bouillon kills a bear & -- \\
\hline $42 \mathrm{v}$ & $\begin{array}{l}\text { Bohemond and Firuz talk on the wall of } \\
\text { Antioch while crusaders prepare to enter }\end{array}$ & de la prinse dantioce \\
\hline $46 r$ & $\begin{array}{l}\text { Saint Andrew shows Peter Bartholemew the } \\
\text { location of the Holy Lance in a dream }\end{array}$ & de saint audrieu \\
\hline $46 \mathrm{v}$ & Crusaders find the Holy Lance & $\begin{array}{l}\text { si comme la lance fu trovee de quoi nostre sires } \\
\text { eut le coste percie }\end{array}$ \\
\hline $47 \mathrm{v}$ & Pre-battle procession in Antioch & la procession qui ala devant et la vraie crois \\
\hline $47 \mathrm{v}$ & Hugh the Great advances to battle at Antioch & la bataille huon le mainsne \\
\hline $47 \mathrm{v}$ & $\begin{array}{l}\text { Robert of Flanders advances to battle at } \\
\text { Antioch }\end{array}$ & la bataille au conte robiert de flandres \\
\hline $47 \mathrm{v}$ & $\begin{array}{l}\text { Robert of Normandy advances to battle at } \\
\text { Antioch }\end{array}$ & la bataille au duc de normandie \\
\hline $48 \mathrm{r}$ & $\begin{array}{l}\text { Adhémar of Le Puy advances to battle at } \\
\text { Antioch }\end{array}$ & la bataille l'evesque du pui nostre dame \\
\hline $48 \mathrm{r}$ & $\begin{array}{l}\text { Raymond of Toulouse advances to battle at } \\
\text { Antioch }\end{array}$ & $\begin{array}{l}\text { la bataille le conte renaut de toouil qui fu la } \\
\text { quinte bataille }\end{array}$ \\
\hline $48 \mathrm{r}$ & $\begin{array}{l}\text { Raimbaud of Orange advances to battle at } \\
\text { Antioch }\end{array}$ & la bataille le conte d'orange \\
\hline $48 \mathrm{r}$ & Godfrey of Bouillon advances to battle at & la septisme godefrois de buillon \\
\hline
\end{tabular}




\begin{tabular}{|c|c|c|}
\hline & Antioch & \\
\hline $48 \mathrm{r}$ & Tancred of Sicily advances to battle at Antioch & le vuitisme bataille li boins tancres li preux \\
\hline $48 v$ & Hugh of St. Pol advances to battle at Antioch & le conte de saint pol \\
\hline $48 v$ & Rotrou of Perch advances to battle at Antioch & le dus de normandie \\
\hline $48 v$ & Ysoard of Die advances to battle at Antioch & buimons \\
\hline $49 \mathrm{r}$ & Crusaders advance to battle at Antioch & ci issi toute l'ost \\
\hline $49 v$ & $\begin{array}{l}\text { Crusaders and Turks fight outside Antioch } \\
\text { among the Turkish tents }\end{array}$ & des turs du donjon \\
\hline $61 \mathrm{r}$ & $\begin{array}{l}\text { Godfrey of Bouillon and crusaders see a vision } \\
\text { of a shining knight on the Mount of Olives }\end{array}$ & du signe que dieux envoia au duc \\
\hline $62 \mathrm{r}$ & $\begin{array}{l}\text { Conquest of Jerusalem, Passion, Ascension, and } \\
\text { Dormition of the Virgin }\end{array}$ & -- \\
\hline $64 v$ & $\begin{array}{l}\text { Procession of the True Cross to the Holy } \\
\text { Sepulchre }\end{array}$ & $\begin{array}{l}\text { si comme la vraie crois fu trovee en leglise du } \\
\text { sepulcre }\end{array}$ \\
\hline $72 \mathrm{r}$ & Coronation of Baldwin I of Jerusalem & le couronnement bauduin \\
\hline $73 r$ & Funeral of Hugh the Great & de la sepulture huon de france \\
\hline $87 \mathrm{r}$ & Coronation of Baldwin II of Jerusalem & $\begin{array}{l}\text { del courounement le conte bauduin le secont } \\
\text { bauduin de bourc qui fu contes de rohais }\end{array}$ \\
\hline $93 r$ & Siege of Tyre & $\begin{array}{l}\text { la prinse de la noble cite de sur qui estoit sour } \\
\text { roce en la mer }\end{array}$ \\
\hline $107 v$ & $\begin{array}{l}\text { Coronation of Baldwin III of Jerusalem with } \\
\text { Melisende present }\end{array}$ & la roi bauduin et sa mere \\
\hline $135 v$ & $\begin{array}{l}\text { Coronation and nuptial mass of Amalric I of } \\
\text { Jerusalem and Marie Comnena }\end{array}$ & $\begin{array}{l}\text { ci fu couronnes li rois et la roine marie sa fame } \\
\text { niece l'empereour }\end{array}$ \\
\hline $140 \mathrm{r}$ & Coronation of Baldwin IV of Jerusalem & le couronnement le roi bauduin qui fu mesiaux \\
\hline $154 \mathrm{v}$ & Sibylla of Jerusalem crowns Guy de Lusignan & comment la contesse couronna son mari \\
\hline
\end{tabular}

Note: Constructed from digital images of the manuscript and Folda's catalog ('The Illustrations in Manuscripts,' 2:251-60).

Figure 1. Five of twelve column miniatures showing the advance to battle outside Antioch (1098), Bibliothèque nationale de France, Paris, MS fr. 352, fol. 48r, mid-fourteenth century (Source: Bibliothèque nationale de France).

Figure 2. Jerusalem with the Passion, Ascension of Christ, and Dormition of the Virgin, Bibliothèque nationale de France, Paris, MS fr. 352, fol. 1r, mid-fourteenth century (Source: Bibliothèque nationale de France).

Figure 3. Conquest of Jerusalem (1099), Bibliothèque nationale de France, Paris, MS fr. 352, fol. 62r, mid-fourteenth century (Source: Bibliothèque nationale de France). 